\title{
Article \\ Serum 25-Hydroxyvitamin D Is Inversely Associated with Monocyte Percentage to HDL Cholesterol Ratio among Young Healthy Adults in Qatar
}

\author{
Hanaa Mousa ${ }^{1,2}$, Nazmul Islam ${ }^{3}$, Vijay Ganji ${ }^{4}(\mathbb{D}$ and Susu M. Zughaier $1,2, *$ (D) \\ 1 College of Medicine, QU Health, Qatar University, Doha P.O. Box 2731, Qatar; hanaa.mousa@qu.edu.qa \\ 2 \#2Biomedical and Pharmaceutical research Unit, QU Health, Qatar University, Doha P.O. Box 2731, Qatar \\ 3 Public Health Department, College of Health Sciences, QU Health, Qatar University, \\ Doha P.O. Box 2731, Qatar; nislam@qu.edu.qa \\ 4 Human Nutrition Department, College of Health Sciences, QU Health, Qatar University, \\ Doha P.O. Box 2731, Qatar; vganji@qu.edu.qa \\ * Correspondence: szughaier@qu.edu.qa; Tel.: +974-4403-7859
}

check for

updates

Citation: Mousa, H.; Islam, N.; Ganji,

V.; Zughaier, S.M. Serum 25-

Hydroxyvitamin D Is Inversely

Associated with Monocyte Percentage to HDL Cholesterol Ratio among Young Healthy Adults in Qatar. Nutrients 2021, 13, 127. https://doi. org/10.3390/nu13010127

Received: 24 November 2020 Accepted: 28 December 2020 Published: 31 December 2020

Publisher's Note: MDPI stays neutral with regard to jurisdictional clai$\mathrm{ms}$ in published maps and institutional affiliations.

Copyright: (C) 2020 by the authors. Licensee MDPI, Basel, Switzerland. This article is an open access article distributed under the terms and conditions of the Creative Commons Attribution (CC BY) license (https:// creativecommons.org/licenses/by/ $4.0 /)$.

\begin{abstract}
Low serum 25-hydroxyvitamin D [25(OH)D] is linked to an altered lipid profile. Monocytes play an important role in inflammation and lipid metabolism. Recently, monocyte percentage to HDL-cholesterol ratio (MHR) has emerged as a novel marker of inflammation. We investigated the association between serum 25(OH)D concentrations and MHR and serum lipids in young healthy adults. Data from the Qatar Biobank were utilized to investigate the relation between serum 25(OH)D and inflammation and serum lipid concentrations in healthy Qatari adults using multivariate regression analysis. Prevalence of serum $25(\mathrm{OH}) \mathrm{D}$ concentrations $<12 \mathrm{ng} / \mathrm{mL}$ (deficiency), $12-20 \mathrm{ng} / \mathrm{mL}$ (insufficiency), and $\geq 20 \mathrm{ng} / \mathrm{mL}$ (sufficiency) were $55.8 \%, 29.9 \%$, and $14.3 \%$, respectively. Serum $25(\mathrm{OH}) \mathrm{D}$ was significantly inversely associated with monocyte percentage, MHR, total cholesterol, LDL-cholesterol, and triacylglycerol in multivariable adjusted analysis. MHR could be a potential biomarker to predict cardiometabolic diseases among young healthy Qataris.
\end{abstract}

Keywords: vitamin D; 25-hydroxyvitamin D; HDL; monocyte percentage; MHR; inflammation

\section{Introduction}

The classical function of vitamin D is to maintain the homeostasis of calcium and phosphorous. Vitamin D can be obtained from the diet and skin exposure to the sun's UVB light. Regardless of the source, in the liver, vitamin D is converted to 25-hydroxyvitamin $\mathrm{D}[25(\mathrm{OH}) \mathrm{D}]$, a major circulatory vitamer. Further, in the kidney, 25(OH)D is converted to 1,25 dihydroxyvitamin $\mathrm{D}\left(1,25(\mathrm{OH})_{2} \mathrm{D}\right)$ by 25 -hydroxyvitamin $\mathrm{D}-1 \alpha$-hydroxylase [1] Non-calcemic effect of vitamin $\mathrm{D}$ is through the action of $25(\mathrm{OH})_{2} \mathrm{D}$ via vitamin $\mathrm{D}$ receptors. Low circulating concentrations of $25(\mathrm{OH}) \mathrm{D}$ is highly prevalent in Qatar. Previous studies conducted in 2012 reported an estimated $90 \%$ of the Qatari population suffer from various degrees of vitamin D insufficiency and deficiency [2]. More recently, Al-Dabhani reported that $64 \%$ of the population in Qatar suffers from vitamin D deficiency [3].

The impact of low vitamin D on health outcomes is well documented [4]. Specifically, vitamin D deficiency is related to several chronic inflammatory diseases [5] such as metabolic syndrome, obesity, and cardiovascular diseases (CVD) [6,7]. Therefore, by improving serum vitamin D may lead to reduced inflammation and CVD [8]. Zughaier et al. [9] reported that the hormonally active $1,25(\mathrm{OH})_{2} \mathrm{D}$ leads to a significant decrease in IL-6 and IL-1 $\beta$ gene expression in monocytes exposed to an inflammatory stimulus such as lipopolysaccharide.

Monocytes are central immune cells that display a wide range of homeostatic and immune response functions. Because monocytes are major secretors of the pro-inflammatory mediators such as cytokines, an increase in monocytes percentage may be an indication 
of sub-clinical inflammation $[10,11]$. Additionally, HDL is a major component of total cholesterol that has been known to have anti-inflammatory and protective functions, hence dubbed as the good cholesterol [12]. Thus, when monocyte percentage is elevated and HDL is reduced, monocyte to HDL cholesterol ratio (MHR) is elevated which suggests a homeostatic perturbations and sub-clinical inflammation. Additionally, vitamin D deficiency has been linked to dyslipidemia such as low HDL-cholesterol [13-15]. However, it is not very clear about the mechanism through which vitamin D exerts its effects on lipids $[16,17]$.

Recently, MHR has been recognized as a novel biomarker of subclinical inflammation [18-20]. The total number of monocytes is inversely related to HDL and MHR is reported to be elevated in many disorders such as hypertension [21], atherosclerosis [22], and diabetic nephropathy [23]. Elevated MHR is associated with disease severity in CVD such as coronary artery stenosis [24,25]. MHR is also associated with a chronic inflammatory condition such as chronic obstructive pulmonary disease [26]. MHR was reported in many studies as an independent prognostic biomarker in many diseases associated with high inflammatory status particularly disorders linked to cardiac disorders or atherosclerotic events. For example, in infective endocarditis patients, MHR alone predicted the in-hospital death with relatively higher sensitivity $(74.4 \%)$ and specificity $(57.6 \%)$ [27]. In acute ischemic stroke, patients with higher MHR showed higher susceptibility to develop clinical complications such as intracranial hemorrhage [28]. However, the association between serum 25(OH)D and MHR is not known yet. Therefore in this study, we investigated the relationship between serum $25(\mathrm{OH}) \mathrm{D}$ concentration and subclinical inflammation biomarker, MHR in healthy young adults in Qatar.

\section{Materials and Methods}

\subsection{Study Design and Study Participants}

This study is a cross-sectional, retrospective study based on the data collected by the Qatar Biobank (QBB). The study sample broadly represents the population of Qatar. Briefly, the QBB collected data on Qataris and non-Qataris who have been living in the country $\geq 15$ years. The participants were $\geq 18$ years old. Data on general health and lifestyle, diet, cognitive function, and physical and clinical measurements were collected. Further, several health and clinical biomarkers were measured in blood, urine, and saliva. The detailed methodologies were described elsewhere [29,30]. Ethical IRB approval (QBB-RES-ACC0237-0142) and confidentiality agreements were obtained before conducting this study. The total number of participants in this study was 874 ; however 14 participants were excluded as gender was missing. Hence, the initial analysis included 860 participants (men, $n=399$; women, $n=461$ ).

The inclusion criteria were young healthy Qatari adults between the ages of 18 and 40 years who did not have any co-morbidities. The exclusion criteria included those using vitamin D supplements and those with CVD, diabetes, hypertension, kidney disease, liver disease, pregnancy, cancer, and critical illness. Thus, the sample contained apparently healthy subjects. Vitamin D status was defined as deficiency, insufficiency, and sufficiency if the serum $25(\mathrm{OH}) \mathrm{D}$ concentrations were $<12 \mathrm{ng} / \mathrm{mL}, 12-<20 \mathrm{ng} / \mathrm{mL}, \geq 20 \mathrm{ng} / \mathrm{mL}$, respectively. This classification was based on the Institute of Medicine's recommendations [31].

Physical and biochemical measurements: Participants' height, weight, and BMI were measured with light clothing by trained nurses. Bodyweight was measured using the TANITA BC-418 MA instrument. BMI was computed using weight in $\mathrm{kg}$ divided by height in $\mathrm{m}^{2}$. Venous blood samples were collected from participants after overnight fasting. Blood specimens were sent to Hamad Medical Corporation Laboratories (College of American Pathologist Accredited Laboratory) for further analysis. Monocytes, white blood cells (WBC), lymphocytes, and neutrophils were measured as part of the differential while blood cell count. All the blood biomarkers such as serum 25(OH)D, plasma glucose, serum HDL cholesterol, serum total cholesterol, serum LDL cholesterol, and serum triacylglycerol were measured all at once. Serum $25(\mathrm{OH}) \mathrm{D}$ concentration (included both vitamin $\mathrm{D}_{2}$ 
and vitamin $\mathrm{D}_{3}$ fractions) was measured using electrochemiluminescence immunoassay (LIAISON $^{\circledR}$ 25-hydroxyvitamin D Total Assay, DiaSorin Inc., Stillwater, MN, USA). Plasma glucose was measured with the enzymatic/amperometric method (Nova statstrip and Roche Accucheck Inform II devices). Serum total cholesterol was measured with enzymatic CHOD-PAP method. HDL cholesterol Plus Third Generation Method was used to measure the serum HDL cholesterol. LDL cholesterol Plus Second Generation Method was used to measure the serum LDL cholesterol. Serum triacylglycerol was measured with enzymatic GPO-PAP method. Detailed methodologies were described elsewhere [29,32].

\subsection{Statistical Analysis}

Baseline characteristics according to the serum $25(\mathrm{OH}) \mathrm{D}$ concentrations were presented as frequencies and percentages for categorical variables and as means (SD) for continuous variables. Data were tested for normality using Shapiro-Wilk test. Histograms were constructed to detect the normality. Although MHR and 25(OH)D concentrations were not normally distributed based on the significance, the histogram revealed that the data were very close to normal. Therefore, regression analysis was performed on nontransformed data. Comparisons between participants with serum 25(OH)D concentrations (sufficient, insufficient, and deficient) were performed using chi-squared Tests (or Fisher exact tests for cells $<5$ ) for categorical variables. ANOVA was used for normally distributed numerical variables and Kruskal-Wallis tests were used for non-normally distributed interval variables. Accordingly, Chi-Squared was used for gender, while ANOVA was used for age, BMI, WBC, monocyte, lymphocyte, neutrophil, neutrophil percentage to HDL ratio (NHR), total cholesterol, LDL, and HDL. Kruskal-Wallis test was used for MHR, lymphocyte percentage to HDL ratio (LHR), WBC percentage to HDL ratio, and triglycerides. Additionally, baseline characteristics between men and women were also reported for selected characteristics. The differences between men and women for monocyte percentage, serum HDL cholesterol, and MHR were tested with an independent, 2-tailed $t$-test.

An association between serum25(OH)D and inflammatory markers and serum lipids were analyzed with multinomial logistic regression using gender, age, BMI, and smoking as confounding variables. In this analysis, the sample size varied from 702 to 706 depending on the variable. We also performed a forward step-wise multinomial regression adding each confounding variable at a time to study the impact of each confounding variable on the relationship between serum 25(OH)D and MHR. In the multinomial logistic regression analysis, $25(\mathrm{OH}) \mathrm{D} \geq 20 \mathrm{ng} / \mathrm{mL}$ category was used as a reference category. Multinomial logistic regression coefficients $(\beta)$ and their $95 \%$ confidence intervals (95\% CI) were reported. Further, an association between serum $25(\mathrm{OH}) \mathrm{D}$ concentrations and inflammatory markers and serum lipids were analyzed with multivariable linear regression using gender, age, BMI, and smoking as confounding variables. In this analysis, all serum 25(OHD, inflammatory markers, and serum lipids were used as continuous variables. Multivariable regression coefficients ( $\beta$ ) and their $95 \%$ confidence intervals (95\% CI) were reported. Additionally, we performed a restrictive Cubic Spline adjusted regression analysis to assess whether the relationship between serum $25(\mathrm{OH}) \mathrm{D}$ concentrations and MHR was linear. For simplicity, we did not report cubic spline analysis between serum $25(\mathrm{OH}) \mathrm{D}$ and other inflammatory markers and serum lipids. All statistical analyses were two-sided. A $p<0.05$ was considered statistically significant. Analyses were performed using the Stata statistical software package 16 (Stata Corp, College Station, TX, USA).

\section{Results}

\subsection{Serum Vitamin D Concentrations in Young Healthy Adults in Qatar}

Table 1 shows the baseline characteristics based on serum $25(\mathrm{OH}) \mathrm{D}$ concentrations. In this study, the prevalence of serum $25(\mathrm{OH}) \mathrm{D}<12 \mathrm{ng} / \mathrm{mL}$ and $\geq 20 \mathrm{ng} / \mathrm{mL}$ were $55.8 \%$ $(n=488)$ and $14.2 \%(n=125)$, respectively. The mean BMI was significantly higher in the vitamin D deficient group $\left(28.3 \mathrm{~kg} / \mathrm{m}^{2}\right)$ in comparison with a sufficient group $\left(26.4 \mathrm{~kg} / \mathrm{m}^{2}\right)$. Monocyte percentage was significantly higher in participants with vitamin $\mathrm{D}$ deficiency 
compared to sufficiency. In the vitamin D sufficient group, the MHR mean was signifcantly lower (5.1) compared to the vitamin D deficiency group (5.8) or the vitamin D insufficiency group (5.7) $(p<0.011)$.

Table 1. Characteristics of the study population based on serum $25(\mathrm{OH}) \mathrm{D}$ concentrations $(n=860)^{1 .}$

\begin{tabular}{|c|c|c|c|c|}
\hline & $\begin{array}{l}\text { Vitamin D Deficiency } \\
(\text { serum } 25(\mathrm{OH}) \mathrm{D},<12 \\
\mathrm{ng} / \mathrm{mL})\end{array}$ & $\begin{array}{l}\text { Vitamin D Insufficiency } \\
\text { (serum } 25(\mathrm{OH}) \mathrm{D}, 12-<20 \\
\mathrm{ng} / \mathrm{mL})\end{array}$ & $\begin{array}{l}\text { Vitamin D Sufficiency } \\
\text { (serum } 25(\mathrm{OH}) \mathrm{D}, \\
\geq 20 \mathrm{ng} / \mathrm{mL} \text { ) }\end{array}$ & $p$-Value ${ }^{2}$ \\
\hline $\mathrm{N}$ & 488 & 261 & 125 & \\
\hline \multicolumn{5}{|l|}{ Gender ${ }^{3}$} \\
\hline Women & $274(56 \%)$ & $131(51 \%)$ & $56(46 \%)$ & ns \\
\hline Men & $214(44 \%)$ & $130(50 \%)$ & $55(44 \%)$ & \\
\hline Age (years) & $28.8(6)$ & $30.3(5.9)$ & $29.8(5.8)$ & 0.002 \\
\hline Body mass index, $\mathrm{kg} / \mathrm{m}^{2}$ & $28.3(6.8)$ & $27.6(5.3)$ & $26.4(5.5)$ & 0.008 \\
\hline White blood cells, cells $/ 10^{9} \mathrm{~L}$ & $6.8(2.0)$ & $6.8(2.0)$ & $6.7(1.8)$ & ns \\
\hline Monocyte, \% & $7.5(1.9)$ & $7.3(1.9)$ & $6.9(1.6)$ & 0.014 \\
\hline Lymphocyte, \% & $35.6(8.6)$ & $35.1(9.4)$ & $36(9.1)$ & ns \\
\hline Neurtophil, \% & $53(9.8)$ & $54.1(10.4)$ & $53.5(10.1)$ & ns \\
\hline Monocyte $\%$ to HDL ratio & $5.8(2.3)$ & $5.7(2.5)$ & $5.1(1.8)$ & 0.011 \\
\hline Lymphocyte \% to HDL ratio & $27.3(10.1)$ & $26.9(11.1)$ & $26(8.4)$ & ns \\
\hline Neutrophil \% to HDL ratio & $41(14)$ & $42(16.2)$ & $39(12.2)$ & ns \\
\hline Total cholesterol, $\mathrm{mmol} / \mathrm{L}$ & $4.8(0.8)$ & $4.8(0.7)$ & $4.6(0.8)$ & ns \\
\hline HDL-cholesterol, $\mathrm{mmol} / \mathrm{L}$ & $1.4(0.4)$ & $1.4(0.4)$ & $1.4(0.3)$ & ns \\
\hline LDL- cholesterol, $\mathrm{mmol} / \mathrm{L}$ & $2.8(0.8)$ & $2.8(0.7)$ & $2.7(0.7)$ & ns \\
\hline Triacylglycerol, mmol/L & $1.2(0.7)$ & $1.1(0.7)$ & $1.0(0.5)$ & ns \\
\hline Glucose, $\mathrm{mmol} / \mathrm{L}$ & $5.0(0.7)$ & $5.0(0.9)$ & $4.9(0.7)$ & ns \\
\hline
\end{tabular}

${ }^{1}$ Data are presented in mean $( \pm \mathrm{SD})$ for continuous measures and $\mathrm{n}(\%)$ for categorical measures; ns: not significant. To convert $\mathrm{ng} / \mathrm{mL}$ to $\mathrm{nmol} / \mathrm{L}$, multiply with 2.496. ${ }^{2}$ Serum vitamin D categorization was based on Institute of Medicine guidelines. ${ }^{3}$ Significance in Chi-Squared test for proportions or ANOVA for continuous measurements.

Additionally, gender differences in selected characteristics were described in Figures 1 and 2. Monocyte percentage was significantly lower in women compared to men, while the HDL was significantly higher in women compared to men $(p<0.001)$. The MHR was significantly lower in women compared to men (Figure 2A). However, the MHR was significantly lower in women compared to men in vitamin D deficient group $(p<0.004)$ but not in vitamin D insufficiency or in sufficiency group (Figure 2B).

A

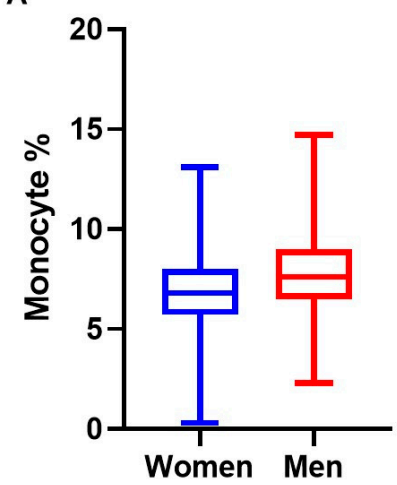

B

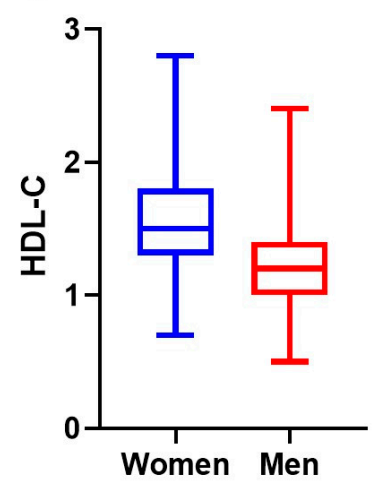

Figure 1. Differences in selected baseline characteristics between men and women. (A): Monocyte percentages in women and men (6.95 vs. 7.87; $p<0.001$ for independent, 2-tailed $t$-statistic). (B): HDL cholesterol concentrations in women and men (1.56 vs. $1.24 \mathrm{mmol} / \mathrm{L} ; p<0.001$ for independent, 2-tailed t-statistic). 
A

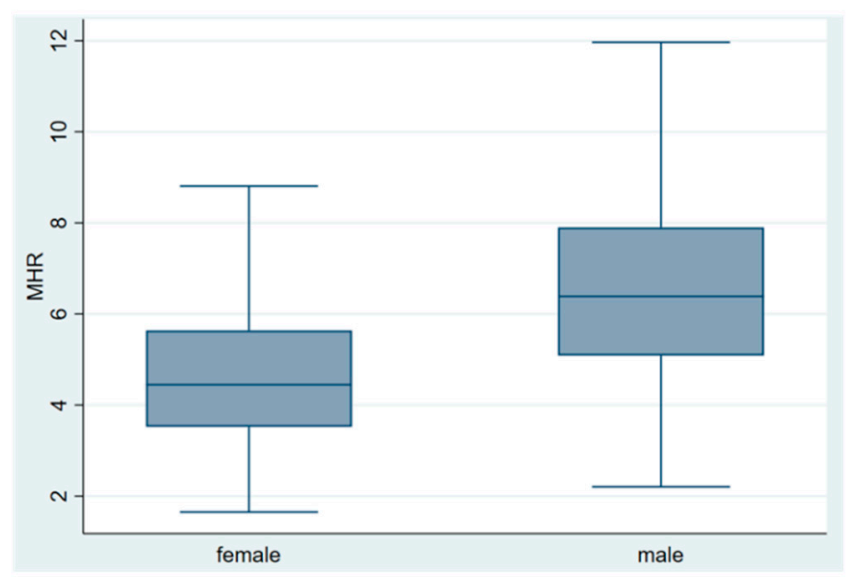

B

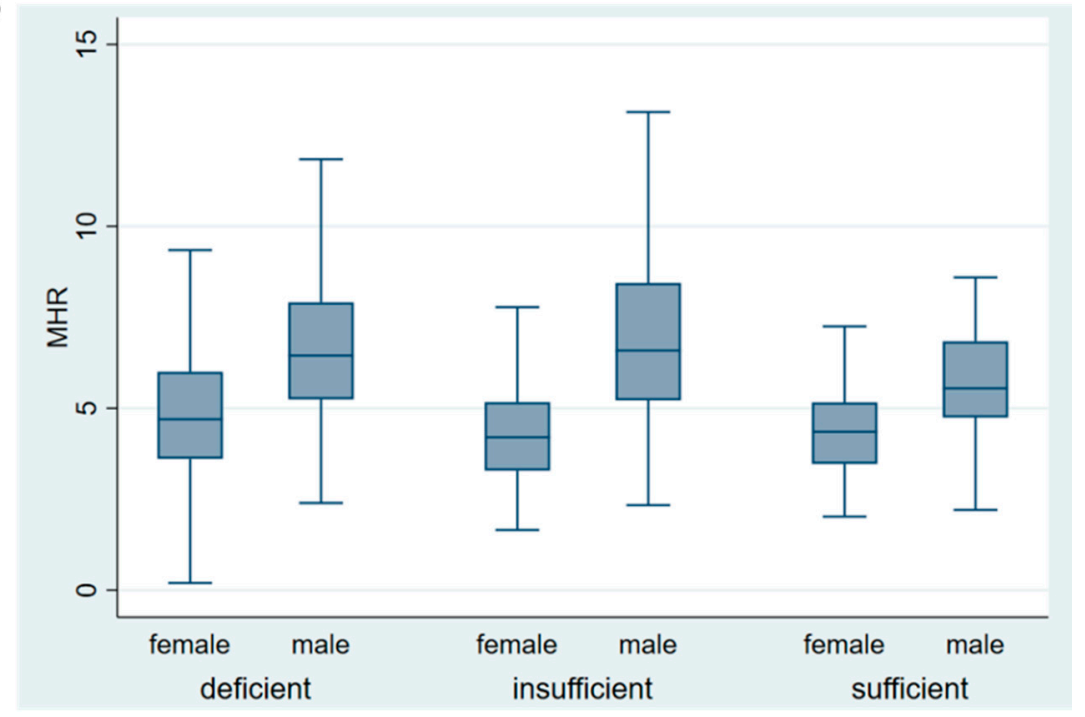

Figure 2. Comparison of MHR based on serum 25(OH)D concentrations in healthy young adults in Qatar. Serum 25(OH)D concenrtations were defined as deficiency $(<12 \mathrm{ng} / \mathrm{mL})$, insufficiency $(12-<20 \mathrm{ng} / \mathrm{mL})$, and sufficiency $(\geq 20 \mathrm{ng} / \mathrm{mL})$. (A): Boxplots of MHR in women compared to men $(p<0.001$ for $t$-statistic). (B): Boxplots of MHR for men and women within vitamin D deficient ( $p<0.004$ for independent, 2-tailed $t$-statistic), vitamin D insufficient ( $p<0.58$ for independent, 2 tailed $t$-statistic), vitamin D sufficient ( $p<0.21$ for independent, 2-tailed $t$-statistic) categories. To convert $\mathrm{ng} / \mathrm{mL}$ to $\mathrm{nmol} / \mathrm{L}$, multiply with 2.496. Abbreviations: 25(OH)D, 25-hydroxyvitamin D; MHR, monocyte percentage to HDL cholesteorl ratio; VitD, vitamin D.

\subsection{Association between Serum 25(OH)D Concentrations and Inflammation Biomarkers and} Serum Lipids

The associtioan between serum $25(\mathrm{OH}) \mathrm{D}$ concentrations and inflammatory markers and serum lipids (categorized form) are presented in Table 2. In the multivariabe regression analysis, a significant association between serum 25(OH)D and MHR was observed in the deficient group, $(\beta=0.19 ; p<0.005)$ in comparison to the sufficient category. Moreover, in vitamin $\mathrm{D}$ insufficient participants, the regression coefficient was $0.15(p<0.03)$. The monocyte percentage coefficient was statistically significant in vitamin D deficient participants $0.19(p<0.006)$ in comparison to the vitamin D sufficient category. In contrast, no associations were observed between serum $25(\mathrm{OH}) \mathrm{D}$ concentration and lymphocyte percentage, neutrophil percentage, LHR, and NHR. Interestingly, in vitamin D deficient participants, serum lipids such as serum total cholesterol $(p<0.014)$, serum LDL-cholesterol $(p<0.03)$, and serum triacylglycerol $(p<0.04)$ but not serum HDL-cholesterol were signifi- 
cantly associated with serum 25(OH)D. Plasma glucose was not significantly assocaited with serum $25(\mathrm{OH}) \mathrm{D}$ concentrations.

Table 2. Association between serum $25(\mathrm{OH}) \mathrm{D}$ concentrations and inflammatory markers and serum lipids in young healthy adults in Qatar ${ }^{1}$.

\begin{tabular}{|c|c|c|c|c|c|c|}
\hline & \multicolumn{2}{|c|}{$\begin{array}{l}\text { Vitamin D Deficiency } \\
(<12 \mathrm{ng} / \mathrm{mL})^{2}\end{array}$} & \multicolumn{2}{|c|}{$\begin{array}{l}\text { Vitamin D Insufficiency } \\
(12-<20 \mathrm{ng} / \mathrm{mL})^{2}\end{array}$} & \multicolumn{2}{|c|}{$\begin{array}{l}\text { Continuous } \\
\text { Association }^{3}\end{array}$} \\
\hline & $\beta(95 \% \mathrm{CI})$ & $p$-Value & $\beta(95 \% \mathrm{CI})$ & $p$-Value & $\beta(95 \% \mathrm{CI})$ & $p$-Value \\
\hline $\begin{array}{l}\text { White blood cell, cells } / 10^{9} \mathrm{~L} \\
\qquad(n=702)\end{array}$ & $0.01(-0.11,0.14)$ & ns & $0.02(-0.11,0.15)$ & ns & $0.09(-0.22,0.41)$ & ns \\
\hline Monocyte \% $(n=702)$ & $0.2(0.06,0.34)$ & 0.006 & $0.09(-0.05,0.24)$ & ns & $-0.54(-0.19,-0.2)$ & 0.002 \\
\hline Lymphocyte \% $(n=702)$ & $-0.01(-0.03,0.02)$ & ns & $-0.02(-0.04,0.01)$ & ns & $0.01(-0.06,0.08)$ & ns \\
\hline Neurtophil \% $(n=702)$ & $-0.01(-0.03,0.02)$ & ns & $0.01(-0.01,0.04)$ & ns & $0.02(-0.03,0.08)$ & ns \\
\hline Monocyte $\%$ to HDL ratio $(n=701)$ & $0.19(0.06,0.32)$ & 0.005 & $0.15(0.02,0.29)$ & 0.03 & $-0.38(-0.66,-0.1)$ & 0.008 \\
\hline $\begin{array}{l}\text { Lymphocyte \% to HDL ratio } \\
\qquad(n=701)\end{array}$ & $0.01(-0.02,0.04)$ & ns & $0.01(-0.02,0.04)$ & $\mathrm{ns}$ & $-0.02(-0.08,0.04)$ & $\mathrm{ns}$ \\
\hline Neutrophil \% to HDL ratio $(n=701)$ & $0.02(-0.004,0.04)$ & ns & $0.01(-0.01,0.02)$ & ns & $0.001(-0.04,0.04)$ & ns \\
\hline Total cholesterol, $\mathrm{mmol} / \mathrm{L}(n=706)$ & $04(0.08,0.72)$ & 0.014 & $0.25(-0.09,0.58)$ & ns & $-1.03,-1.81,-0.26)$ & 0.009 \\
\hline HDL-cholesterol, $\mathrm{mmol} / \mathrm{L}(n=706)$ & $-0.2(-0.94,0.54)$ & ns & $-0.22(-0.1,0.58)$ & ns & $0.54(-1.42,2.4)$ & ns \\
\hline LDL- cholesterol, mmol/L ( $n=703)$ & $0.4(0.05,0.74)$ & 0.03 & $0.27(-0.1,0.63)$ & ns & $-0.98(-1.84,-0.12)$ & 0.026 \\
\hline Triacylglycerol, $\mathrm{mmol} / \mathrm{L}(n=706)$ & $0.49(0.02,0.93)$ & 0.04 & $0.31(-0.16,0.78)$ & ns & $-1.06(-2.0,-0.11)$ & 0.028 \\
\hline Glucose, $\mathrm{mmol} / \mathrm{L}(n=706)$ & $0.2(0.18,0.58)$ & ns & $0.1(-0.26,0.55)$ & ns & $-0.34(-1.2,0.49)$ & ns \\
\hline
\end{tabular}

${ }^{1}$ Persons with chronic diseases and who were taking prescription medication were not included in the study. To convert ng/mL to $\mathrm{nmol} / \mathrm{L}$, multiply with 2.496. Abbreviations: $25(\mathrm{OH}) \mathrm{D}, 25$-hydroxyvitamin $\mathrm{D} ; \beta$, regression coefficient; ns, not significant. ${ }^{2}$ Multinomial logistic regression analysis was adjusted for gender, age, BMI, and smoking. Serum Vitamin D categorization (deficiency, insufficiency, and sufficiency) was based on Institute of Medicine guidelines. Vitamin D sufficiency $(\geq 20 \mathrm{ng} / \mathrm{mL})$ was used as a referent category. ${ }^{3}$ Multivariable regression analysis was adjusted for gender, age, BMI, and smoking. Serum 25(OH)D and inflammatory markers and serum lipids were used as continuous variables.

Additionally, the multivariable associations between serum25(OH)D and inflammatory biomarkers and serum lipids (continuous form) are presented in Table 2. We observed a significant inverse relation between serum $25(\mathrm{OH}) \mathrm{D}$ and monocytes percentage, $(\beta=-0.54$; $p<0.002)$, MHR, $(\beta=-0.38 ; p<0.008)$, serum total cholesterol, $(\beta=-1.03 ; p<0.009)$, serum LDL cholesterol, $(\beta=-0.98 ; p<0.026)$, and serum triacylglycerol $(\beta=-1.06 ; p<0.028)$. The relationship in continuous variable regression analysis, between serum $25(\mathrm{OH}) \mathrm{D}$ and monocytes percentage, MHR, and serum total cholesterol, LDL cholesterol, and triacylglycerol was much stronger compared to the multinomial logistic regression.

Serum 25(OH)D had a linear relationship with MHR in Restricted Cubic Spline multivariable adjusted regression analysis when analyzed as continuous variables. In both logarithmic transformed and non-transformed analyses, we observed a significant linear relationship between serum 25(OH)D and MHR $(p<0.001)$ (Figure 3). In stepwise forward regression analyses, age, gender, BMI, and smoking were significantly related in all regression models. However for simplicity, in Figure 3, we only reported the multivariable adjusted relationship between non-transformed serum 25(OHD and MHR in a continuous form (without categorization of serum 25(OH)D concentrations). 


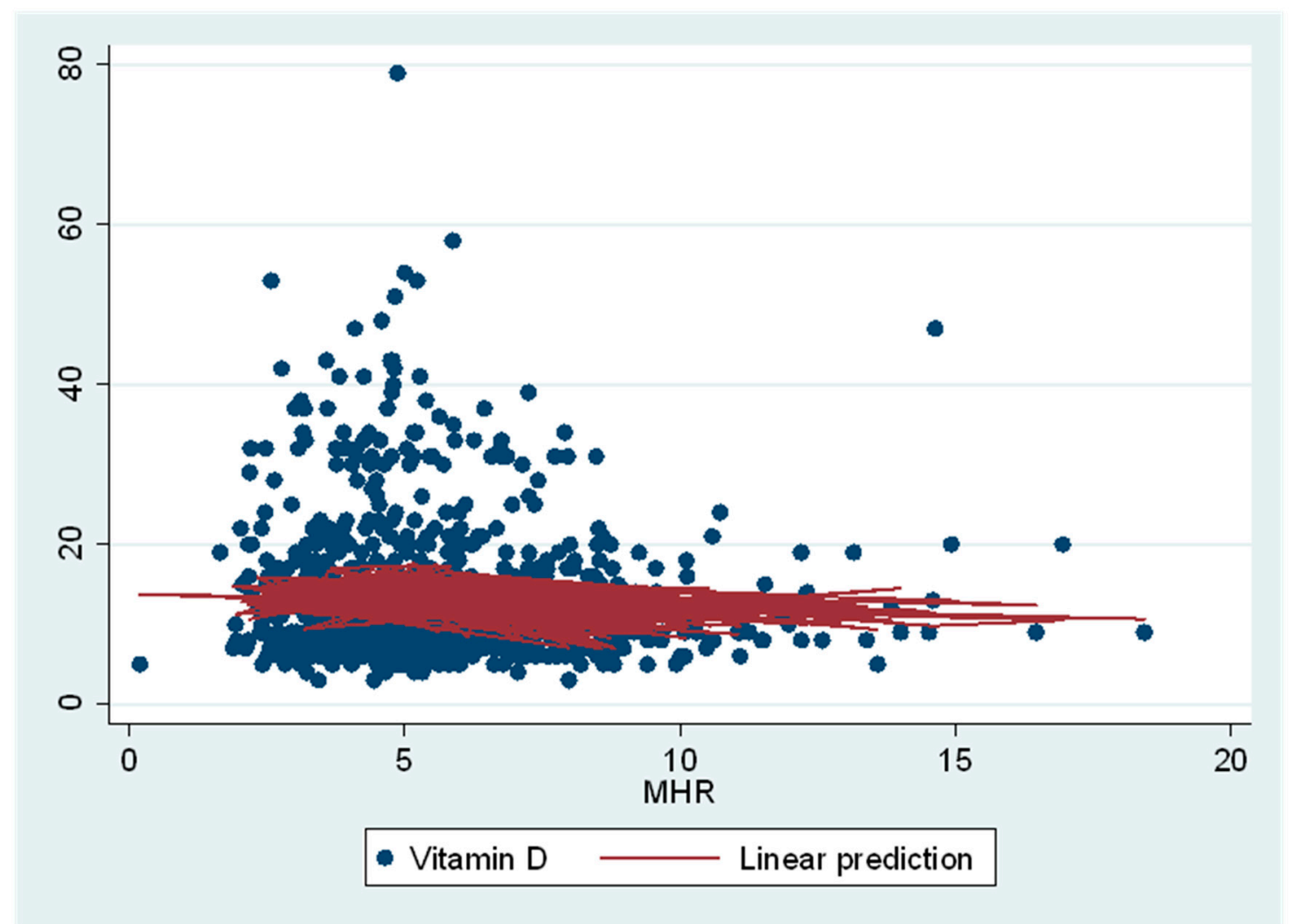

Figure 3. Restricted Cubic Spline Regression between serum 25(OH)D concentration and MHR after adjustment for age, gender, BMI, and smoking in young health adults in Qatar $(\mathrm{n}=701)$. Serum $25(\mathrm{OH}) \mathrm{D}$ and MHR were used as continuous variables. Linear relationship between serum $25(\mathrm{OH}) \mathrm{D}$ and $\mathrm{MHR}$ is significant $(p<0.001)$. Abbreviations: $25(\mathrm{OH}) \mathrm{D}$, 25-hydroxyvitamin D; MHR, monocyte percentage to HDL cholesterol ratio.

\section{Discussion}

We have investigated the relationship between serum 25(OH)D concentrations and MHR and serum lipids in healthy young Qatar population. This is the first study to report an inverse relationship between 25(OH)D and MHR. This relationship was measured in using 2 separate statistical procedures, i.e., stepwise multinomial adjusted logistic regression using serum $25(\mathrm{OHD}$ as categorical variable and multivariable adjusted linear regression using $25(\mathrm{OH}) \mathrm{D}$ and inflammatory markers and serum lipids as a continuous variables. In categorized analysis, vitamin D deficiency was significantly related to MHR. In the continuous regression, serum $25(\mathrm{OH}) \mathrm{D}$ was significantly, inversely related to MHR and serum lipids. It is interesting to note that based on regression coefficients, the relationship was much stronger in the continuous regression analysis.

MHR is an emerging novel maker of CVD [33] such as ischemic stroke [34] and cerebral hemorrhage [35]. Elevated MHR is an indicator of systemic inflammation as well as oxidative stress [18]. In disorders like polycystic ovary syndrome, MHR was found to be more sensitive than the usual markers such as increased BMI and C-reactive protein (CRP) in predicting disease development [36]. Moreover, MHR is reported to predict the severity and complication in diseases such as obstructive sleep apnea, and MHR was used to anticipate the cardiovascular sequels [37]. MHR also demonstrated efficiency in predicting short-term mortality in patients with ST-segment elevation myocardial infarction [38].

Elevation in monocyte percentage can occur in infection, inflammation, and other cellular perturbations such as autoimmunity disorders, thus reflecting clinical inflammation [39]. Monocyte percentage elevation suggests more perturbation and inflammatory cytokine release, whereas absolute monocyte number vary among participants and gender. Therefore, in this study, monocyte percentage is used to better reflect sub-clinical inflamma- 
tion status. Vitamin D is known to exert anti-inflammatory effects on monocytes leading to reduced proinflammatory cytokines release and reprogramming of cells $[9,40]$. Vitamin $\mathrm{D}$ deficiency is observed in various chronic inflammatory diseases indicating the antiinflammatory effect of vitamin D [41] We found a significant inverse association between serum vitamin D and the subclinical inflammation marker, MHR, among healthy young adults. This relation could be explained by several mechanisms. Vitamin D is a suppressor of endoplasmic reticulum stress leading to downregulation of adhesion molecules such as PSGL-1, $\beta(1)$-integrin, and $\beta(2)$-integrin, consequently, decreasing the monocytes activation [42]. Furthermore, vitamin D possesses an immunomodulatory effect and regulates monocyte inflammatory responses by attenuating cellular signaling and pro-inflammatory genes activation, subsequently preventing cytokines release. For example, Vitamin D attenuates TLR2 and TLR4 mediated signaling leading to reduction in TNF $\alpha$ release, and activation of intracellular inflammatory pathways like p38 and NF-kB pathway [43].

Epidemiological studies showed a significant relation between low concentrations of serum $25(\mathrm{OH}) \mathrm{D}$ and the risk of infections and hospitalization [44,45]. For instance, the risk of acute lower respiratory tract infection is reported to be higher in children who suffer from vitamin D deficiency in the first two years of life [46]. In support, vitamin D supplementation demonstrated a protective effect against acute respiratory tract infections [47]. Further, vitamin D deficiency is prevalent in several inflammatory diseases, such as inflammatory bowel disease [48], and rheumatoid arthritis [49]. In systemic lupus erythematosus, vitamin $\mathrm{D}$ induces reconstruction of the balance between $\mathrm{B}$ and $\mathrm{T}$ cells through stimulating an increase in CD4+ T cells and a decrease of memory B cells and anti-DNA antibodies [50]. Moreover, in cancer patients, a meta-analysis study illustrates an enhanced overall survival in patients who have higher serum $25(\mathrm{OH}) \mathrm{D}$ concentrations [51]. The given data suggest that the importance of vitamin $\mathrm{D}$ as an anti-inflammatory and an antioxidant nutrient metabolite. A recent retrospective study found a negative relation between serum 25(OH)D concentrations and CRP (a marker of inflammation and cytokine storm), in COVID-19 patients, which again indicates a protective role of vitamin D in reducing inflammation [52].

The association between vitamin D deficiency and dyslipidemia, i.e., low HDL, high LDL, and high triacylglycerol is well documented [15]. Studies reported a significant association between serum 25(OH)D concentrations and HDL. Subjects with sufficient serum 25(OH)D concentrations have higher concentrations of HDL, while deficient subjects have significantly lower HDL concentration [13,53]. Further, sufficient HDL is shown to be protective in CVD and other chronic diseases [54]. However, in this young healthy adult cohort, we did not observe any significant associations between serum $25(\mathrm{OH}) \mathrm{D}$ concentrations and the HDL profile as this sample is selected to be devoid of co-morbidities, which may explain the lack of association in this study. Additionally, it has been known that anti-dyslipidemia drugs affect HDL cholesterol concentrations. Consequently, MHR measurements would be affected accordingly. However, we were unable to investigate the potential confounding effect on the relationship between serum $25(\mathrm{OH}) \mathrm{D}$ and MHR as this study sample did not contain subjects who were taking anti-lipidemic medications. Further, this might be interesting to study this confounding effect in older cohort.

The importance of this study is that it highlights the association between serum 25(OH)D concentrations and the novel biomarker MHR. This association could be utilized to predict the risk of progressing into diseases like metabolic syndrome and dyslipidemia. Recent studies investigated whether lymphocytes and neutrophils as predictors of inflammation. LHR and NHR along with MHR were good predictive biomarkers of inflammatory diseases such as metabolic syndrome $[55,56]$. In our study, we found no association between serum 25(OH)D and LHR and NHR. This is probably due to sample selection criteria; young healthy adults who do not have any underlying disorders. However, thus far, no study reported an association between 25(OHD concentrations and LHR and NHR.

The cross-sectional design of the study is one of the study limitations. Therefore, the cause and effect should not be assumed. Moreover, this study is conducted on healthy 
young adults, which explains the modest changes in HDL and MHR. If the study population is older, we may have a higher MHR and perhaps a stronger association between serum 25(OH)D concentrations and MHR. Further, in this study, we did not correct for general confounders like socioeconomic status as the cohort are all Qataris without drastic differences in demography, and with relatively high socioeconomic status. Therefore, the lack of adjustment for this variable, might not affected the outcome. Future studies are warranted to confirm the association of serum vitamin D with MHR in an older population with or without chronic inflammatory conditions. In conclusion, serum $25(\mathrm{OH}) \mathrm{D}$ concentrations is inversely associated with the MHR, a novel subclinical inflammation biomarker.

Author Contributions: Conceived the study: S.M.Z.; data collection: S.M.Z. and H.M.; data analysis: H.M., N.I., S.M.Z., and V.G.; supervision: S.M.Z.; writing manuscript draft: H.M., S.M.Z., and V.G. All authors have read and agreed to the published version of the manuscript.

Funding: This work is funded by a graduate student grant QUST-2-CMED-2019-6 from Qatar University.

Institutional Review Board Statement: The study was conducted according to the guidelines of the Declaration of Helsinki, and approved by the Institutional Review Board of Qatar Biobank, Doha, Qatar (QBB-RES-ACC-0237-0142) and confidentiality agreements were obtained before conducting this study.

Informed Consent Statement: Informed consent was obtained from all subjects involved in the study.

Data Availability Statement: Restrictions apply to the availability of these data. Data was obtained from Qatar Biobank (https:/ / www.qatarbiobank.org.qa) under confidentiality agreement with Qatar University.

Acknowledgments: We acknowledge Qatar Biobank, Doha, Qatar, for providing the data used in this study.

Conflicts of Interest: The authors declare no conflict of interest.

\section{References}

1. Bikle, D. Vitamin D: Production, Metabolism, and Mechanisms of Action. In Endotext; Feingold, K.R., Anawalt, B., Boyce, A., Chrousos, G., Dungan, K., Grossman, A., Hershman, J.M., Kaltsas, G., Koch, C., Kopp, P., et al., Eds.; MDText.com, Inc.: South Dartmouth, MA, USA, 2000.

2. Badawi, A.; Arora, P.; Sadoun, E.; Al-Thani, A.A.; Thani, M.H. Prevalence of vitamin d insufficiency in qatar: A systematic review. J. Public Health Res. 2012, 1, 229-235. [CrossRef] [PubMed]

3. Al-Dabhani, K.; Tsilidis, K.K.; Murphy, N.; Ward, H.A.; Elliott, P.; Riboli, E.; Gunter, M.; Tzoulaki, I. Prevalence of vitamin D deficiency and association with metabolic syndrome in a Qatari population. Nutr. Diabetes 2017, 7, e263. [CrossRef] [PubMed]

4. Matyjaszek-Matuszek, B.; Lenart-Lipińska, M.; Woźniakowska, E. Clinical implications of vitamin D deficiency. Prz. Menopauzalny 2015, 14, 75-81. [PubMed]

5. Zughaier, S.M.; Lubberts, E.; Bener, A. Editorial: Immune-Modulatory Effects of Vitamin D. Front. Immunol. 2020, 11, 2385. [CrossRef]

6. Wang, H.; Chen, W.; Li, D.; Yin, X.; Zhang, X.; Olsen, N.; Zheng, S.G. Vitamin D and Chronic Diseases. Aging Dis. 2017, 8, 346-353. [CrossRef]

7. Ganji, V.; Zhang, X.; Shaikh, N.; Tangpricha, V. Serum 25-hydroxyvitamin D concentrations are associated with prevalence of metabolic syndrome and various cardiometabolic risk factors in US children and adolescents based on assay-adjusted serum 25-hydroxyvitamin D data from NHANES 2001-2006. Am. J. Clin. Nutr. 2011, 94, 225-233. [CrossRef]

8. Yin, K.; Agrawal, D.K. Vitamin D and inflammatory diseases. J. Inflamm. Res. 2014, 7, 69-87.

9. Zughaier, S.M.; Alvarez, J.A.; Sloan, J.H.; Konrad, R.J.; Tangpricha, V. The role of vitamin D in regulating the iron-hepcidinferroportin axis in monocytes. J. Clin. Transl. Endocrinol. 2014, 1, 19-25. [CrossRef]

10. Kantari, C.; Pederzoli-Ribeil, M.; Witko-Sarsat, V. The role of neutrophils and monocytes in innate immunity. Contrib. Microbiol. 2008, 15, 118-146.

11. Chapman Caroline, M.L.; Beilby John, P.; McQuillan Brendan, M.; Thompson Peter, L.; Hung, J. Monocyte Count, But Not C-Reactive Protein or Interleukin-6, Is an Independent Risk Marker for Subclinical Carotid Atherosclerosis. Stroke 2004, 35, 1619-1624. [CrossRef]

12. Tall, A.R.; Yvan-Charvet, L. Cholesterol, inflammation and innate immunity. Nat. Rev. Immunol. 2015, 15, 104-116. [CrossRef] [PubMed] 
13. Sarmiento-Rubiano, L.A.; Angarita Ruidiaz, J.A.; Suarez Davila, H.F.; Suarez Rodriguez, A.; Rebolledo-Cobos, R.C.; Becerra, J.E. Relationship between Serum Vitamin D Levels and HDL Cholesterol in Postmenopausal Women from Colombian Caribbean. J. Nutr. Metab. 2018, 2018, 9638317. [CrossRef] [PubMed]

14. AlQuaiz, A.M.; Kazi, A.; Youssef, R.M.; Alshehri, N.; Alduraywish, S.A. Association between standardized vitamin 25(OH)D and dyslipidemia: A community-based study in Riyadh, Saudi Arabia. Environ. Health Prev. Med. 2020, 25, 4. [CrossRef] [PubMed]

15. Jiang, X.; Peng, M.; Chen, S.; Wu, S.; Zhang, W. Vitamin D deficiency is associated with dyslipidemia: A cross-sectional study in 3788 subjects. Curr. Med. Res. Opin. 2019, 35, 1059-1063. [CrossRef]

16. Schmitt, E.B.; Nahas-Neto, J.; Bueloni-Dias, F.; Poloni, P.F.; Orsatti, C.L.; Petri Nahas, E.A. Vitamin D deficiency is associated with metabolic syndrome in postmenopausal women. Maturitas 2018, 107, 97-102. [CrossRef]

17. Pan, G.T.; Guo, J.F.; Mei, S.L.; Zhang, M.X.; Hu, Z.Y.; Zhong, C.K.; Zeng, C.Y.; Liu, X.H.; Ma, Q.H.; Li, B.Y.; et al. Vitamin D Deficiency in Relation to the Risk of Metabolic Syndrome in Middle-Aged and Elderly Patients with Type 2 Diabetes Mellitus. J. Nutr. Sci. Vitam. (Tokyo) 2016, 62, 213-219. [CrossRef]

18. Katipoglu, Z.; Mirza, E.; Oltulu, R.; Katipoglu, B. May Monocyte/HDL Cholesterol Ratio (MHR) and Neutrophil/Lymphocyte Ratio (NLR) Be an Indicator of Inflammation and Oxidative Stress in Patients with Keratoconus? Ocul. Immunol. Inflamm. 2020, 28, 632-636. [CrossRef]

19. Osadnik, T.; Bujak, K.; Osadnik, K.; Czarnecka, H.; Pawlas, N.; Reguła, R.; Fronczek, M.; Lejawa, M.; Gawlita, M.; Gonera, M.; et al. Novel inflammatory biomarkers may reflect subclinical inflammation in young healthy adults with obesity. Endokrynol. Pol. 2019, 70, 135-142. [CrossRef]

20. Çakýr, I.; Arifoðlu, H.B.; Ekici Günay, N.; Pangal, E.; Pahin, D.; Alýcý Sert, G.; Duru, N. Monocyte to High-Density Lipoprotein Ratio: A Novel Inflammation Marker Related to Diabetic Retinopathy. Ercýyes Med. J. 2020, 42, 190-194. [CrossRef]

21. Yayla, K.G.; Canpolat, U.; Yayla, Ç.; Akboğa, M.K.; Akyel, A.; Akdi, A.; Çiçek, G.; Ozcan, F.; Turak, O.; Aydoğdu, S. A Novel Marker of Impaired Aortic Elasticity in Never Treated Hypertensive Patients: Monocyte/High-Density Lipoprotein Cholesterol Ratio. Acta Cardiol. Sin. 2017, 33, 41-49.

22. Tani, S.; Matsumoto, M.; Anazawa, T.; Kawamata, H.; Furuya, S.; Takahashi, H.; Iida, K.; Washio, T.; Kumabe, N.; Kobori, M.; et al. Development of a model for prediction of coronary atherosclerotic regression: Evaluation of high-density lipoprotein cholesterol level and peripheral blood monocyte count. Heart Vessel. 2012, 27, 143-150. [CrossRef] [PubMed]

23. Karatas, A.; Turkmen, E.; Erdem, E.; Dugeroglu, H.; Kaya, Y. Monocyte to high-density lipoprotein cholesterol ratio in patients with diabetes mellitus and diabetic nephropathy. Biomark. Med. 2018, 12, 953-959. [CrossRef] [PubMed]

24. Korkmaz, A.; Demir, M.; Unal, S.; Yildiz, A.; Ozyazgan, B.; Demirtas, B.; Elalmis, O.U.; Ileri, M.; Guray, U. Monocyte-to-high density lipoprotein ratio (MHR) can predict the significance of angiographically intermediate coronary lesions. Int. J. Cardiovasc. Acad. 2017, 3, 16-20. [CrossRef]

25. Kim, J.-H.; Lee, Y.-J.; Park, B. Higher monocyte count with normal white blood cell count is positively associated with 10-year cardiovascular disease risk determined by Framingham risk score among community-dwelling Korean individuals. Medicine 2019, 98 (Suppl. 61), e15340. [CrossRef]

26. Yakar, H.I.; Kanbay, A.; Ceylan, E. Could Monocyte /HDL cholesterol ratio predict cardiovascular events in patients with Chronic Obstructive Pulmonary Disease? Eur. Respir. J. 2017, 50, PA1007.

27. Wei, X.B.; Chen, F.; Huang, J.L.; He, P.C.; Wei, Y.X.; Tan, N.; Chen, J.Y.; Yu, D.Q.; Liu, Y.H. Novel Risk Biomarker for Infective Endocarditis Patients With Normal Left Ventricular Ejection Fraction- Monocyte to High-Density Lipoprotein Cholesterol Ratio. Circ. J. 2017, 82, 283-288. [CrossRef]

28. Oh, S.W.; Yi, H.J.; Lee, D.H.; Sung, J.H. Prognostic Significance of Various Inflammation-Based Scores in Patients with Mechanical Thrombectomy for Acute Ischemic Stroke. World Neurosurg. 2020, 141, e710-e717. [CrossRef]

29. Al Thani, A.; Fthenou, E.; Paparrodopoulos, S.; Al Marri, A.; Shi, Z.; Qafoud, F.; Afifi, N. Qatar Biobank Cohort Study: Study Design and First Results. Am. J. Epidemiol. 2019, 188, 1420-1433. [CrossRef]

30. Al Kuwari, H.; Al Thani, A.; Al Marri, A.; Al Kaabi, A.; Abderrahim, H.; Afifi, N.; Qafoud, F.; Chan, Q.; Tzoulaki, I.; Downey, P.; et al. The Qatar Biobank: Background and methods. BMC Public Health 2015, 15, 1208. [CrossRef]

31. Ross, A.C.; Taylor, C.L.; Yaktine, A.L.; HB, D.V. Institute of Medicine (US) Committee to Review Dietary Reference Intakes for Vitamin D and Calcium. In Dietary Reference Intakes for Calcium and Vitamin D; National Academies Press: Washington, DC, USA, 2011.

32. Matthews, D.R.; Hosker, J.P.; Rudenski, A.S.; Naylor, B.A.; Treacher, D.F.; Turner, R.C. Homeostasis model assessment: Insulin resistance and beta-cell function from fasting plasma glucose and insulin concentrations in man. Diabetologia 1985, 28, 412-419. [CrossRef]

33. Ganjali, S.; Gotto Jr, A.M.; Ruscica, M.; Atkin, S.L.; Butler, A.E.; Banach, M.; Sahebkar, A. Monocyte-to-HDL-cholesterol ratio as a prognostic marker in cardiovascular diseases. J. Cell. Physiol. 2018, 233, 9237-9246. [CrossRef] [PubMed]

34. Bolayir, A.; Gokce, S.F.; Cigdem, B.; Bolayir, H.A.; Yildiz, O.K.; Bolayir, E.; Topaktas, S.A. Monocyte/high-density lipoprotein ratio predicts the mortality in ischemic stroke patients. Neurol. Neurochir. Pol. 2018, 52, 150-155. [CrossRef] [PubMed]

35. You, S.; Zhong, C.; Zheng, D.; Xu, J.; Zhang, X.; Liu, H.; Zhang, Y.; Shi, J.; Huang, Z.; Cao, Y.; et al. Monocyte to HDL cholesterol ratio is associated with discharge and 3-month outcome in patients with acute intracerebral hemorrhage. J. Neurol. Sci. 2017, 372, 157-161. [CrossRef] [PubMed] 
36. Usta, A.; Avci, E.; Bulbul, C.B.; Kadi, H.; Adali, E. The monocyte counts to HDL cholesterol ratio in obese and lean patients with polycystic ovary syndrome. Reprod. Biol. Endocrinol. 2018, 16, 34. [CrossRef]

37. Li, N.; Ren, L.; Wang, J.H.; Yan, Y.R.; Lin, Y.N.; Li, Q.Y. Relationship between monocyte to HDL cholesterol ratio and concomitant cardiovascular disease in Chinese Han patients with obstructive sleep apnea. Cardiovasc. Diagn. 2019, 9, 362-370. [CrossRef]

38. Sercelik, A.; Besnili, A.F. Increased monocyte to high-density lipoprotein cholesterol ratio is associated with TIMI risk score in patients with ST-segment elevation myocardial infarction. Rev. Port. Cardiol. (Engl. Ed.) 2018, 37, 217-223. [CrossRef]

39. Karlmark, K.R.; Tacke, F.; Dunay, I.R. Monocytes in health and disease-Minireview. Eur. J. Microbiol. Immunol. 2012, 2, 97-102. [CrossRef]

40. Zhang, Y.; Leung, D.Y.M.; Richers, B.N.; Liu, Y.; Remigio, L.K.; Riches, D.W.; Goleva, E. Vitamin D Inhibits Monocyte/Macrophage Proinflammatory Cytokine Production by Targeting MAPK Phosphatase-1. J. Immunol. 2012, 188, 2127. [CrossRef]

41. Wöbke, T.K.; Sorg, B.L.; Steinhilber, D. Vitamin D in inflammatory diseases. Front Physiol 2014, 5, 244. [CrossRef]

42. Riek, A.E.; Oh, J.; Sprague, J.E.; Timpson, A.; de las Fuentes, L.; Bernal-Mizrachi, L.; Schechtman, K.B.; Bernal-Mizrachi, C. Vitamin D suppression of endoplasmic reticulum stress promotes an antiatherogenic monocyte/macrophage phenotype in type 2 diabetic patients. J. Biol. Chem. 2012, 287, 38482-38494. [CrossRef]

43. Sadeghi, K.; Wessner, B.; Laggner, U.; Ploder, M.; Tamandl, D.; Friedl, J.; Zugel, U.; Steinmeyer, A.; Pollak, A.; Roth, E.; et al. Vitamin D3 down-regulates monocyte TLR expression and triggers hyporesponsiveness to pathogen-associated molecular patterns. Eur. J. Immunol. 2006, 36, 361-370. [CrossRef] [PubMed]

44. Buonomo, A.R.; Zappulo, E.; Scotto, R.; Pinchera, B.; Perruolo, G.; Formisano, P.; Borgia, G.; Gentile, I. Vitamin D deficiency is a risk factor for infections in patients affected by HCV-related liver cirrhosis. Int. J. Infect. Dis. 2017, 63, 23-29. [CrossRef] [PubMed]

45. Ingham, T.R.; Jones, B.; Camargo, C.A.; Kirman, J.; Dowell, A.C.; Crane, J.; Stanley, T.V.; Grimwood, K.; The Whiti Te Ra Study, G. Association of vitamin D deficiency with severity of acute respiratory infection: A case-control study in New Zealand children. Eur. Respir. J. 2014, 44 (Suppl. 58), 439.

46. Mohamed, W.A.; Al-Shehri, M.A. Cord blood 25-hydroxyvitamin D levels and the risk of acute lower respiratory tract infection in early childhood. J. Trop. Pediatr. 2013, 59, 29-35. [CrossRef] [PubMed]

47. Martineau, A.R.; Jolliffe, D.A.; Hooper, R.L.; Greenberg, L.; Aloia, J.F.; Bergman, P.; Dubnov-Raz, G.; Esposito, S.; Ganmaa, D.; Ginde, A.A.; et al. Vitamin D supplementation to prevent acute respiratory tract infections: Systematic review and meta-analysis of individual participant data. BMJ 2017, 356, i6583. [CrossRef] [PubMed]

48. Levin, A.D.; Wadhera, V.; Leach, S.T.; Woodhead, H.J.; Lemberg, D.A.; Mendoza-Cruz, A.C.; Day, A.S. Vitamin D deficiency in children with inflammatory bowel disease. Dig. Dis. Sci. 2011, 56, 830-836. [CrossRef]

49. Kostoglou-Athanassiou, I.; Athanassiou, P.; Lyraki, A.; Raftakis, I.; Antoniadis, C. Vitamin D and rheumatoid arthritis. Adv. Endocrinol. Metab. 2012, 3, 181-187. [CrossRef]

50. Terrier, B.; Derian, N.; Schoindre, Y.; Chaara, W.; Geri, G.; Zahr, N.; Mariampillai, K.; Rosenzwajg, M.; Carpentier, W.; Musset, L.; et al. Restoration of regulatory and effector $\mathrm{T}$ cell balance and $\mathrm{B}$ cell homeostasis in systemic lupus erythematosus patients through vitamin D supplementation. Arthritis Res. 2012, 14, R221. [CrossRef]

51. Li, M.; Chen, P.; Li, J.; Chu, R.; Xie, D.; Wang, H. Review: The impacts of circulating 25-hydroxyvitamin D levels on cancer patient outcomes: A systematic review and meta-analysis. J. Clin. Endocrinol. Metab. 2014, 99, 2327-2336. [CrossRef]

52. Daneshkhah, A.; Agrawal, V.; Eshein, A.; Subramanian, H.; Roy, H.K.; Backman, V. The Possible Role of Vitamin D in Suppressing Cytokine Storm and Associated Mortality in COVID-19 Patients. medRxiv 2020. [CrossRef]

53. Alkhatatbeh, M.J.; Amara, N.A.; Abdul-Razzak, K.K. Association of 25-hydroxyvitamin D with HDL-cholesterol and other cardiovascular risk biomarkers in subjects with non-cardiac chest pain. Lipids Health Dis. 2019, 18, 27. [CrossRef] [PubMed]

54. Gordon, D.J.; Probstfield, J.L.; Garrison, R.J.; Neaton, J.D.; Castelli, W.P.; Knoke, J.D.; Jacobs, D.R., Jr.; Bangdiwala, S.; Tyroler, H.A. High-density lipoprotein cholesterol and cardiovascular disease. Four prospective American studies. Circulation 1989, 79, 8-15. [CrossRef] [PubMed]

55. Chen, T.; Chen, H.; Xiao, H.; Tang, H.; Xiang, Z.; Wang, X.; Zou, H. Comparison of the Value of Neutrophil to High-Density Lipoprotein Cholesterol Ratio and Lymphocyte to High-Density Lipoprotein Cholesterol Ratio for Predicting Metabolic Syndrome Among a Population in the Southern Coast of China. Diabetes Metab. Syndr. Obes. 2020, 13, 597-605. [CrossRef] [PubMed]

56. Chen, H.; Xiong, C.; Shao, X.; Ning, J.; Gao, P.; Xiao, H.; Chen, Y.; Zou, Z.; Hong, G.; Li, X.; et al. Lymphocyte To HighDensity Lipoprotein Ratio As A New Indicator Of Inflammation And Metabolic Syndrome. Diabetes Metab. Syndr. Obes. 2019, 12, 2117-2123. [CrossRef] [PubMed] 